\title{
Consumer environmental consciousness and brand preference in rivers state
}

\author{
Godswill Chinedu Chukwu', PhD. \\ ${ }^{1}$ Department of Marketing, \\ Ignatius Ajuru University of Education \\ Port Harcourt, Rivers state Nigeria \\ gdwills202@yahoo.com \\ Miyene Charles Tom ${ }^{2}$ \\ ${ }^{1}$ Department of Marketing, \\ Ignatius Ajuru University of Education \\ Port Harcourt, Rivers state Nigeria \\ Miyenetom31@gmail.com
}

\begin{abstract}
This study investigated consumer environmental consciousness and brand preference in Rivers State. The study sought to establish the extent to which brand sound influence repeat purchase of power generating plants, the extent to which brand heat generation influence customer referral of power generating plants and the extent which green protection determine customer loyalty of power generating plants in Rivers State.The study adopted descriptive research design. A population of 52 loyal customers of 5 different brands of power generating plants was randomly selected while 47 questionnaires were successfully retrieved for the study. Data was collected by use of questionnaire from the respondents. Three research questions were posed and three hypotheses were tested. Data were analysed using descriptive statistics (mean and standard deviation) while inferential statistics Pearson Product Moment Correlation (PPMC) was used to test the above stated hypotheses at 0.05 level of significance. The researcher utilized the Cronbach's Alpha for Reliability Statistics to arrive at 0.75 coefficient reliability, Findings revealed that there is a great correlation between brand sound and customer repeat purchase of power generating plants in Rivers state, that there is a low correlation between brand heat generation and customer referral of power generating plant in Rivers State and that there is a great correlation between green protection and customer loyalty of power generating plant in Rivers State. Consumers in Rivers State should be loyal to power generating plants that emit less carbon monoxide for green house protection.
\end{abstract}

\section{Introduction}

The human environment had been subjected to practices and activities which threatening survival in quest for comfort and satisfactions through inventions and innovations of sophisticated mechanical productions with pressure on the natural environment. In discussing this issue Pulse (2016) posits that everywhere on the planet, individuals are confronting a plenty of testing environmental issues each day. A portion of these issues are irrelevant and just influence a couple of biological systems, however others are definitely changing the scene of the earth we've generally known. Anthropogenic challenges which are caused for the most part by human impedance with the environment as talked about by Miller and Spolman (2009) are populace development, inefficient and impractical asset use, neediness, just as deficient information on how nature functions. Additionally, Ofomata and Phil-Eze (2007) recognized the helpless utilization of the standards of environmental administration as a significant reason for a portion of the environmental difficulties on the planet. Human exercises underway of refined actualize like force plants, agrarian apparatuses and other old style machines add to environmental corruption and contamination. These environmental difficulties, for example, an unnatural weather change, over use of regular assets, depletion of the stratospheric ozone layer, commotion contamination, air and water contamination, if not checked will drive humankind from presence, (Ibimilua, and Adewale, 2014). As 
per Ibimilua, and Adewale, (2014) these impacts are unpredictable and multi-dimensional. They fluctuate here and there and every once in a while. They likewise vary as per their causative factor(s) force, occasion span, seriousness, or the intricacy of the process. Freeman, Michael and Muthukumara (2003) presented that environmental fiascos can have more negative impacts on man and different living beings. Essentially, Cunningham and Cunningham (2006) attest that environmental risks are impactsly affecting our reality and different creatures with which we share it. The results influence man, creatures, properties and different parts of the environment. They impact the physical, social, social, financial and prosperity of man. Among the results of environmental difficulties are biodiversity misfortune, new water corruption, environmental change, stratospheric ozone depletion, land debasement, deforestation, and beach front corruption. Different aftermaths are environmental change, hydrological upset, malady flare-up, and stratospheric ozone depletion, (Ibimilua, \& Adewale, 2014). Most of these challenges however is functions of human activities in quest for comfort and satisfaction.

The realization of these issues had created a global interest for protecting and improving the environment through the production and usage of environmental friendly equipment's and gadgets and also consumer education on the choice of equipment in consumption that have environmental safety bearing. This consideration therefore left consumers with the choice of product selections given environmental consequences as discussed as consumer environmental consciousness. Consumer environmental consciousness alludes to the mental variables that decide people's inclination towards favorable to environmental practices, (Zelezny and Schultz, 2000). In thinking about environmental security, consumers are driven by numerous variables, for example, brand sound, heat age and green assurance and so forth.

Sound assumes a basic function in clients' day by day communication with products, frequently impacting their psychological cycles, their feelings, and all the more for the most part their conduct. As this acknowledgment grabs hold, an ever increasing number of organizations start to take a functioning enthusiasm for the acoustic plan of their products, (Lageat, Czellar, and Laurent, 2003).Sounds can likewise be separated between because of the feelings they inspire. Tangible agreeableness was one of the factors that described similitude inside sound classes in Bone bright's study (2001). While best warmth contamination in our territory is warm contamination.

As indicated by the Department of Energy, diesel and gas fueled vehicles created 1,511 million metric huge amounts of $\mathrm{CO} 2$ in 2012, around 29 percent of all vitality related carbon dioxide emanations in the US. The ignition cycle that powers most vehicles creates $\mathrm{CO} 2$, which most atmosphere researchers accept is a significant reason for an Earth-wide temperature boost, (Hearst Seattle Media 2019).Carbon monoxide, nitrogen oxides, and hydrocarbons are delivered when fuel is scorched in an inside burning motor and when air/fuel residuals are radiated through the vehicle tailpipe. Gas fumes likewise escape into the air during refueling and when fuel disintegrates from motors and fuel frameworks brought about by vehicle activity. These posture dangers on our green environments. The concoction delivered influences the green house and furthermore harm lung tissue and can prompt and disturb respiratory illnesses, for example, asthma. Awareness of the impact and the negative effect of these products on the environment control consumers in products preference which is communicated in repeat purchase, products referral and brand loyalty.

Brand preference mirrors a longing to utilize a specific organization's products or administrations, in any event, when there are similarly valued and similarly accessible other options, (Orin, 2019). Actually, as a rule, brand preference shows a longing to search out a particular product or administration, in any event, when it requires paying more or consuming more exertion to acquire it. Brand preference is critical to organizations since it gives a pointer of their clients' loyalty, the accomplishment of their advertising strategies, and the quality of their particular brands. In preferring a brand, purchases are repeated. The more positive the relationship between the customer and the brand is, the more often the customer buys same products from the company which in turn influences the company's' turnover positively,(Govers and Schoormans 2005). This relationship is effective when 
products meet customers' taste in recognizes the satisfaction and environmental implication of the product. Another way consumer demonstrates brand preference is by referring products. Referral marketing is the technique for elevating items or administrations to new clients through referrals, for the most part informal. Likewise, brand loyalty means that brand preference. Item loyalty or brand loyalty is the inclination of consumers to consistently purchase one brand's items over another.

\section{Statement of the Problem}

Human activities contribute major threat to our present environment. This is evident in the manufacturing process where solid, liquid and gaseous wastes are release into our environment unleashing havoc on our general survival. Also, combusting engines such as fuel engines, diesel engines, gas-turbine engines, and rocket-impetus frameworks produce environmental contaminations which are commonly destructive to living creature and the environment everywhere (David, 2003). Dwight (2007) states that the inward burning engine is generally accepted to have been an environmental damage. It has been blamed for hurting our wellbeing by decreasing air quality and adding to what exactly is presently professed to be the most compromising of every single environmental issue, a dangerous global warming.

Consumer environmental consciousness in brand preference had received volumes of academic concern in debate and empirical research given product concern and space consideration. However there is no existing literature which study consumer environmental consciousness in Rivers State which had created knowledge gap in the academic spheres and therefore sought to be filled by this research. This research is titled consumer environmental consciousness on brand preference: A study of selected power generating sets in Rivers State.

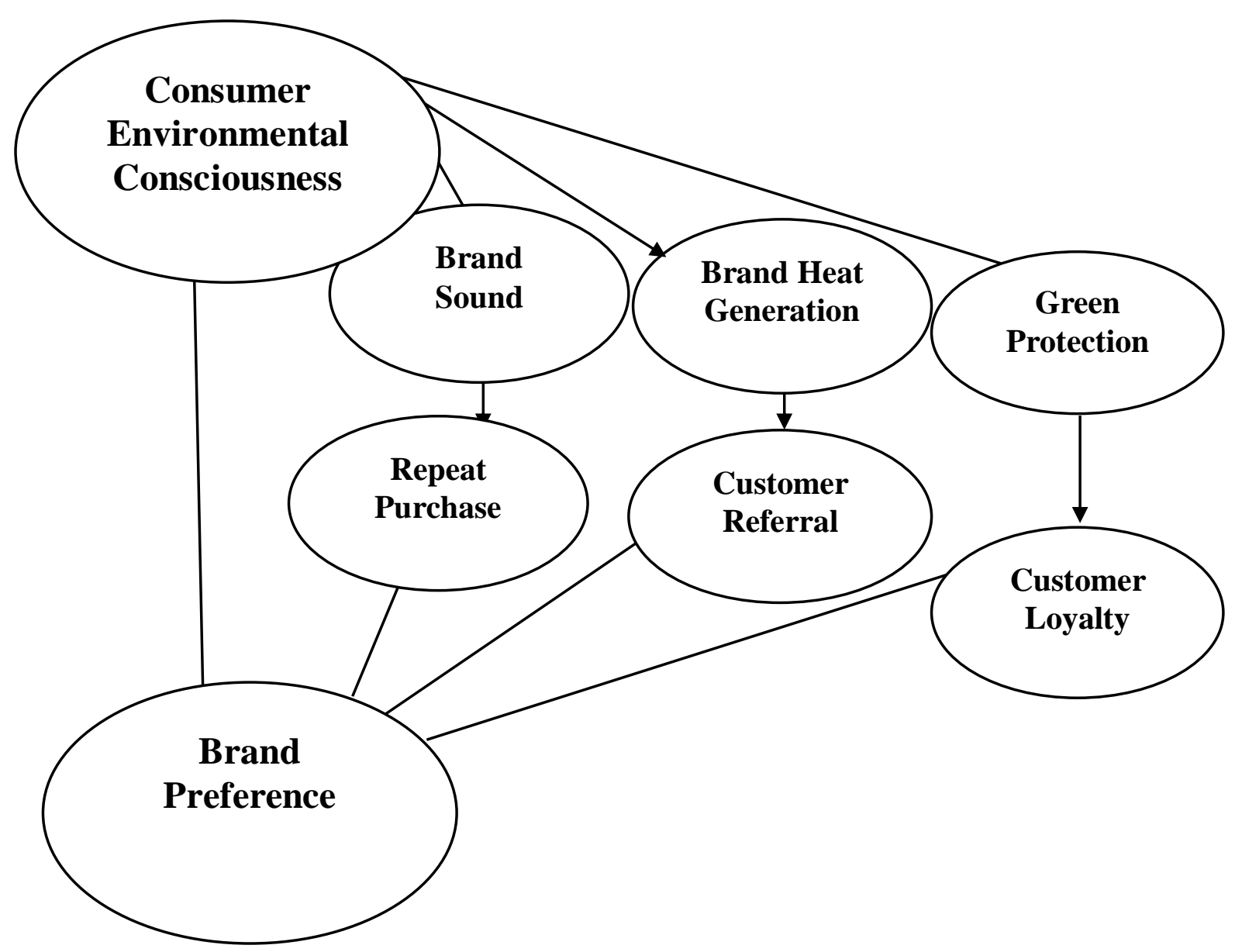




\section{Purpose of Study}

The main purpose of the study is to investigate the impact of consumer environmental consciousness on brand preference in Rivers State. Specific objectives of the study are:

1. To examine the extent to which brand sound influence repeat purchase of power generating plant in Rivers State.

2. To find out the extent to which brand heat generation influence customer referral of power generating plant in Rivers State.

3. To investigate the extent to which green protection determine customer loyalty of power generating plant in Rivers State.

\section{Research Questions}

The research questions that guided this study are as follows:

1. To what extent does brand sound influence repeat purchase of power generating plant in Rivers State?

2. To what extent does brand heat generation influence customer referral of power generating plant in Rivers State?

3. To what extent does green protection determine customer loyalty of power generating plant in Rivers State?

\section{Research Hypotheses}

In order to achieve the objectives of this study, the following hypotheses were formulated;

Ho1: There is no significant relationship between brand sound and repeat purchase of power generating plant in Rivers State.

Ho2: There is no significant relationship between brand heat generation and customer referral of power generating plant in Rivers State.

Ho3: There is no significant relationship between green protection and customer loyalty of power generating plant in Rivers State.

\section{Review of Related Literature}

\section{Conceptual Framework}

\section{Consumer Environmental Consciousness}

Environmental consciousness to allude to explicit mental variables identified with people's affinity to participate in supportive of environmental practices (Zelezny and Schultz 2000:367). With its cause during the 60s in the West, ECO was obvious among people of a gathering who shunned buying certain merchandise due to their environmentally unsafe results (Grunert and Juhl, 1995). From a logical point of view, a biologically cognizant individual or favorable to environmentalist is somebody who participates in a wide scope of pro-environmental practices just as holding certain qualities and mentalities that various speculations have related to this sort of direct. Perceived thusly, environmental consciousness is equal to what in particular can be considered the attitudinal (or mental) measurement of supportive of environmental conduct, (Manuel, and Regina, 2010). Environmentally delicate conduct like monitoring normal assets is a decent marker to aim to purchase environmentally inviting clothing products. Retailers and advertisers may need to urge understudies to know the significance of environmentally delicate practices and to include in those practices, (Seahee, 2011).

\section{Dimensions of Consumer Environmental Consciousness Brand Sound}

Consumers are encircled by an assortment of product-related sounds extending from autos, electronic hardware, and apparatuses to give some examples. The sounds that exude from a product while it is utilized or expended are a basic aspect of consumers' multisensory product experience. For some 
product classes, for example, vehicles, homegrown durables, and innovative products, consumers see hear-able prompts to be similarly as significant as obvious signals (Schifferstein, 2006).

Certain sound-significance correspondences simply sound right. Sound imagery- the connection among sound and importance - can impact brand discernments. For example, names with front vowels, as Beeee, appear to be littler, quicker, and more honed than names with back vowels, as Booooo, which appear to be bigger, more slow, and rounder (Klink 2000). Consumers favor brand names with sounds that propose attractive product properties. Subsequently, frozen yogurt with the smooth sounding name BFrosh is wanted to a similar frozen yogurt with the less velvety sounding name BFrish. There are various reasons why consumers may lean toward specific sounds. As per the phonetic recurrence hypothesis, individuals instinctually partner low-recurrence sounds with forcefulness, and highrecurrence sounds with accommodation (Krishna 2012). These affiliations turned out to be organically designed, as confirmed by fMRI research demonstrating that errands including sound emblematic words lead to expanded actuation in certain mind districts (Revill, Namy, DeFife, \& Nygaard, 2014). Agreeable frequencies may suggest pleasantness or collaboration, making these sounds all the more for the most part engaging.

\section{Brand Heat Generation}

The most effective heat pollution in our locality is thermal pollution. Thermal Pollution occurs because of the thermal power plants, nuclear power plants, fossil fuel like coal, natural gas, oil etc. A large number of heats are rejected to the environment every day from these power plants, (Iftekhar, Arnab, Ali, Shidujaman, \& Mayen, 2013).Most mechanize equipment's in use generate heat to our environment in an extreme volume which are harmful to man and other organism. Power generator in particular has become a common source of heat to our general environment. This consistently raises concern following the rising case of power outage in a country like Nigeria. Heat generated in a mechanical form affects the greenhouse gases. Greenhouse gases are trapping more heat in the Earth's atmosphere, which is causing average temperatures to rise all over the world. Temperatures have risen during the last 30 years, and 2001 to 2010 was the warmest decade ever recorded, (EPA's Climate Change Indicators 2016).

\section{Green Protection}

Environmental protection is the general responsibility of humanity since we feed from it and also live by it. On the contrary human's technological manufacturing releases gases which are harmful into the environment which created greenhouse impact. Carbon dioxide is known to add to the greenhouse impact - a wonder that traps heat in the lower portions of the World's climate. kesh (2019) states that the significant greenhouse gases (GHG's) exclusively liable for greenhouse impact are Carbon dioxide, Ozone, Methane and Water fume. Petroleum products like coal, oil and flammable gas have become a necessary aspect of our life. They are utilized on huge premise to create power and for transportation.

At the point when they are singed, the carbon put away inside them is delivered which consolidates with oxygen noticeable all around to make carbon dioxide. With the expansion in the populace, the quantity of vehicles had additionally expanded and this has brought about increment in the contamination in the environment, (Rinkesh, 2019). At the point when these vehicles run, they discharge carbon dioxide, which is one the primary gas liable for increment in greenhouse effect. Climatologists have connected rising degrees of carbon dioxide with the continuous increment of worldwide normal temperatures brought about by human exercises. This "greenhouse impact" is a characteristic marvel, and it's fundamental for endurance on earth. Nonetheless, as force plants consume more fuel to make more vitality, the additional carbon squander traps an excess of warmth. This can detrimentally affect our territory and our lives.

\section{Concept of Brand Preference}

Brand preferences speak to consumer demeanors to support a specific brand (Overby and Lee, 2006). It 
alludes to the conduct inclinations mirroring the degree to which consumers favor one brand over another (Hellier, Geursen, Carr, and Rickard, 2003). Brand preference is near reality regarding reflecting consumer assessment of brands. In the commercial center, consumers frequently face circumstances of choosing from a few choices (Dhar, 1999). Preferences encourage consumers' decision by improving their goals towards the supported brand. Real buying conduct is probably going to compare to aims; the system of goal arrangement gives proof of relentless consumer preferences (Van Kerckhove, Geuens, and Vermier 2012). Thusly, understanding brand preferences contributes in building solid brands ready to construct long haul relationship with consumers. It is significant for advertisers to know how consumers compromise between various brands before settling on their decisions. Since the brand preference has direct effect on consumer buying choices, at that point dividing the market dependent on brand preference is more interpretable and authoritatively helpful than utilizing the ideal brand properties.

\section{Repeat Purchase}

A repeat purchase is the purchase by a consumer of an equivalent brand product as purchased on a past event. A repeat purchase is a pointer of a level of client loyalty to a brand. It is likewise an open door for advertisers to set up long haul client connections. A high number of repeat purchases show a fulfilled and "very much held" client, which lessens new-client procurement expenses and expands by and large productivity. The business' repeat purchase rate might be expanded utilizing web and webbased media advancements, computerized loyalty programs, and excellent client organization, (Lambert, 2005).

Another outcome of customer patronage is repeat purchase. The more positive the relationship between the customer and the company is, the more often the customer buys products from the company which in turn influences the company's' turnover positively. This is in agreement with salesadjusted retention suggested as measure of customer patronage. Fishbein and Ajzen (1975) concurred that the consumers' purchase conduct is a fundamental list to foresee consumer conduct as an abstract connection to the product. Purchase conduct can be deciphered as the likelihood that the consumers will plan or purchase a specific product or organization later on. Consumers' purchase aim likewise fills in as a middle person between their mentality towards an uncommon product and their genuine purchase conduct.

\section{Product Referral}

Referral advertising is the strategy for elevating products or organizations to new clients through referrals, typically verbal. Such referrals frequently happen unexpectedly however organizations can impact this through fitting techniques. Basically, referral showcasing is getting the news out about a product or organization through a business' current clients, as opposed to customary publicizing. Verbal showcasing, which happens when others reveal to one another about a business, is likewise viewed as a type of referral promoting. Informal exchange is the guideline behind things that "become web news.

In the view of Oliver (1997) cited in Amankwe (2013) submitted that positive word of mouth recommendations is an outcome of customer retention which improves customer patronage. He maintained that customers who are satisfied with the administration of a company will not only stay with the company but will become apostles as well as advocate of the company, thereby recommending the company to other people.

\section{Brand Loyalty}

A brand loyalty shows that consumers pick a brand among contending brands and not acknowledge some other as substitute (Kotler and Keller, 2003). Clients lean toward brands as per their pay level and the estimation of the brand which is otherwise called product execution. Product picture is the part which assumes a powerful function in the brand preference and that picture dependent on consumer's mindfulness and related data about products, (Najam, \& Maryam, 2016). The individuals having a place with working class like to lean toward cost as driving component to choose a product then again the quality, execution or bundle of a product brand are for the most part considered by 
exclusive class individuals. That is the reason the cost is the component which is initially analyzed among various brands of products by the consumers. Individuals generally like to purchase product which gave incredible quality with low cost with different fulfillments (Kwok, Uncles, and Huang, 2006). The five components of settling on the choice about picking a brand, for example, worth or value, nature of the product, brand support, brand promotion and brand inclusion.

\section{Theoretical Framework}

The theories that guide this work are the theory of environmentally responsible behavior by Hines, Hungerford and Tomera (1987).

\section{Theory of Environmentally Responsible Behavior (ERB)}

The ERB theory was proposed by Hines, Hungerford and Tomera (1987). The model contends that having an aim of acting is a main consideration impacting Environmental Dependable Conduct. The Model of Mindful Environmental Conduct demonstrates that the accompanying factors; expectation to act, locus of control (a disguised feeling of individual authority over the occasions in one's own life), mentalities, feeling of moral obligation, and information .proposed whether an individual would receive a conduct or not. Consequently, the theory focuses more on existing associations between boundaries that impact an individual's conduct than on the particular effect of a solitary variable. In squander the board measures, no single factor is answerable for current practices or adequate to start conduct or cause conduct change. For example, individuals heap up their waste materials in the roads in enormous urban communities like Ibadan, Port Harcourt, Jos and so forth., in spite of guidelines from squander the board specialists, restricting these demonstrations. A significant number of these flouters do as such at odd hours when law implementation organizations are not accessible, others are affected to unpredictably dump these waste materials since they see others doing as such, yet some despite everything discover methods of sufficiently arranging off their waste materials.

From the model, information alone is terribly inadequate to act dependably towards the environment, while a few people's information on the environment and its guidelines could provoke them to have a decent mentality which could make an interpretation of to well-meaning goals to act, others may experience the inside and outer control, for example, being affected by the activities of others or holding unequivocally to a conviction to act appropriately regardless of the activities of others towards the environment. Albeit, separate develops of perspectives, control focus and goal of acting may not be sufficient for making a goal to act, joined under one general idea they become a base on which inclinations for favorable to environmental conduct are framed.

\section{Empirical Review}

Muhammad, A. H., Muhammad, F. K. \& Ali, A. (2014)

Muhammad, Muhammad, and Ali, (2014) led an exploration named, Green Mindfulness Consequences for Consumers' Buying Choice: An Instance of Pakistan. To inspect the impact of consumers' environmental concerns, consciousness of green product, cost and brand picture on their buying choice of green products in Pakistan. The advantageous testing method was used with surveys for information assortment. Measurable Bundle for Social Sciences (SPSS) was utilized to perform information examination to check the relationship between green mindfulness and consumer's purchasing choice. Finding uncovered that an individual who has some concern for the environment and its brand picture would have a stronger preference in buying a green product. The investigation subsequently suggested that: Advertisers should accentuation on giving clear information about green products and eco-marks to promote consumer acquaintance with products and enhance their insight into green products. Attractive green product message substance should be aggressively built up that would animate interest among the matured 20 years of age and above. Consumers ought to have the option to effectively differentiate green products from the no green dependent on the labels. Further, the cost on the green products should be affordable to energize purchase. Government and non-government associations are a solid predictor that assumes a significant part in empowering consumers to make strides toward environmental friendliness and grasp green buying conduct. 


\section{Reham, E., Ahmad, G., Zahir, I. \& Ying F. (2016)}

Reham,Ahmad,Zahir,\&Ying, (2016) completed an exploration named, Brand preference and repurchase aim model: the part of consumer experience. To build up a model that gives a comprehension of how brand information and brand experience decide brand preference and research its effect on brand repurchase expectation in Egypt. This examination received the distinct exploration plan with the utilization of polls for information assortment. Exploratory factor examination (EFA) was utilized with head segment investigation (PCA) and VARIMAX symmetrical turn for product decrease for information investigation. Discoveries uncovered that: picking up consumer preferences require conveying a sufficient parity of the brand implications, emblematic impact of the brand on preference is applied through its capacity to reflect or communicate the ideal personality of the consumer. These discoveries suggested that Consumers see this effect either by coordinating or encountering the brand, not by depicting the brand utilizing human characteristics. The examination proposes the significance of encountering the brand so as to move the inborn estimation of brand traits into brand preferences. With regards to innovative products, the function of brand character in forming consumers' brand experience ought to be stressed.

\section{Summary of Literature Review}

The review focuses on consumer environmental consciousness and brand preference. The human environment is susceptible to destruction by human's activities and some natural causes. Such human activities like sound generation which causes noise pollution, heat generation which causes global warming and greenhouse effect which involve the release of carbon monoxide into the atmosphere causing weather fluctuation and air pollution are environmentally destructive with gross inconveniencies on man and other living organism had been succinctly discussed in this work. Two recent empirical research which relate to this study were reviewed while the research adopt the theory of Environmentally Responsible Behavior (ERB) by Hines, Hungerford and Tomera and the Theory of Consumer Behavior by Assael were adopted for this work.

\section{Methodology}

The study adopted the descriptive survey design as it involves the collection of data to accurately and objectively describing existing phenomena, (Isangedighi, Joshua, Asim \& Ekuri, 2006). The population of the study is the customers of five (5) different brands of power generating plants in Rivers State. . A sample size of fifty two (52) respondents was randomly selected and administered the questionnaire. Sample size was derived by the application of Taro Yamane formula. The questionnaire contains 12 questions for the independent variable 'Consumer Environmental Consciousness', and also 12 questions for the dependent variable 'Brand Preference', patterned after the modified 5-point likert scales with response options such as: to very large extent; to large extent; to moderate extent; to low extent and very low extent. The instrument was delivered directly to the respondents with the help of two (2) assistants who were trained by the researchers from Rivers State University. The instrument was validated by two experts in Measurement and Evaluation in the department of educational foundation IAUE. Reliability was measured using test- retest method for its measure of consistency and stability of the instrument and a reliability coefficient of 0.82 was gotten which shows an acceptable level of reliability. Data were analysed using descriptive statistics (mean and standard deviation) while inferential statistics Pearson Product Moment Correlation (PPMC) was used to test the above stated hypotheses at 0.05 level of significance.

\section{Result of Findings}

A total of fifty two (52) respondents were administered the questionnaire. Only forty seven (47) respondents which represent $90 \%$ correctly filled and were retrieved. 
Table 4.1: Questionnaire Respondent Distribution and Retrieval

\begin{tabular}{ccccc}
$\begin{array}{c}\text { Brands of Power } \\
\text { Generator/Plant }\end{array}$ & $\begin{array}{c}\text { Total Number of } \\
\text { Respondents }\end{array}$ & $\begin{array}{c}\text { Respondents } \\
\text { Correctly } \\
\text { Filled }\end{array}$ & $\begin{array}{c}\text { Respondents } \\
\text { Incorrectly } \\
\text { Filled }\end{array}$ & $\begin{array}{c}\text { Percentage } \\
\mathbf{\%}\end{array}$ \\
HONDA & 11 & 9 & 2 & 17 \\
ELEPAQ & 12 & 11 & 1 & 23 \\
SUMEC & 11 & 10 & 1 & 18 \\
FIRMAN & 8 & 8 & 0 & 15 \\
PERKINS & 10 & 9 & 1 & 17 \\
Total & $\mathbf{5 2}$ & $\mathbf{4 7}$ & $\mathbf{5}$ & $\mathbf{9 0}$ \\
\hline
\end{tabular}

Source: Field survey, 2019

\section{Research Question 1}

To what extent does brand sound influence repeat purchase of power generating plant in Rivers State? Figure 4. 1: represent is a bar chart showing the responses of the respondents to research question one.

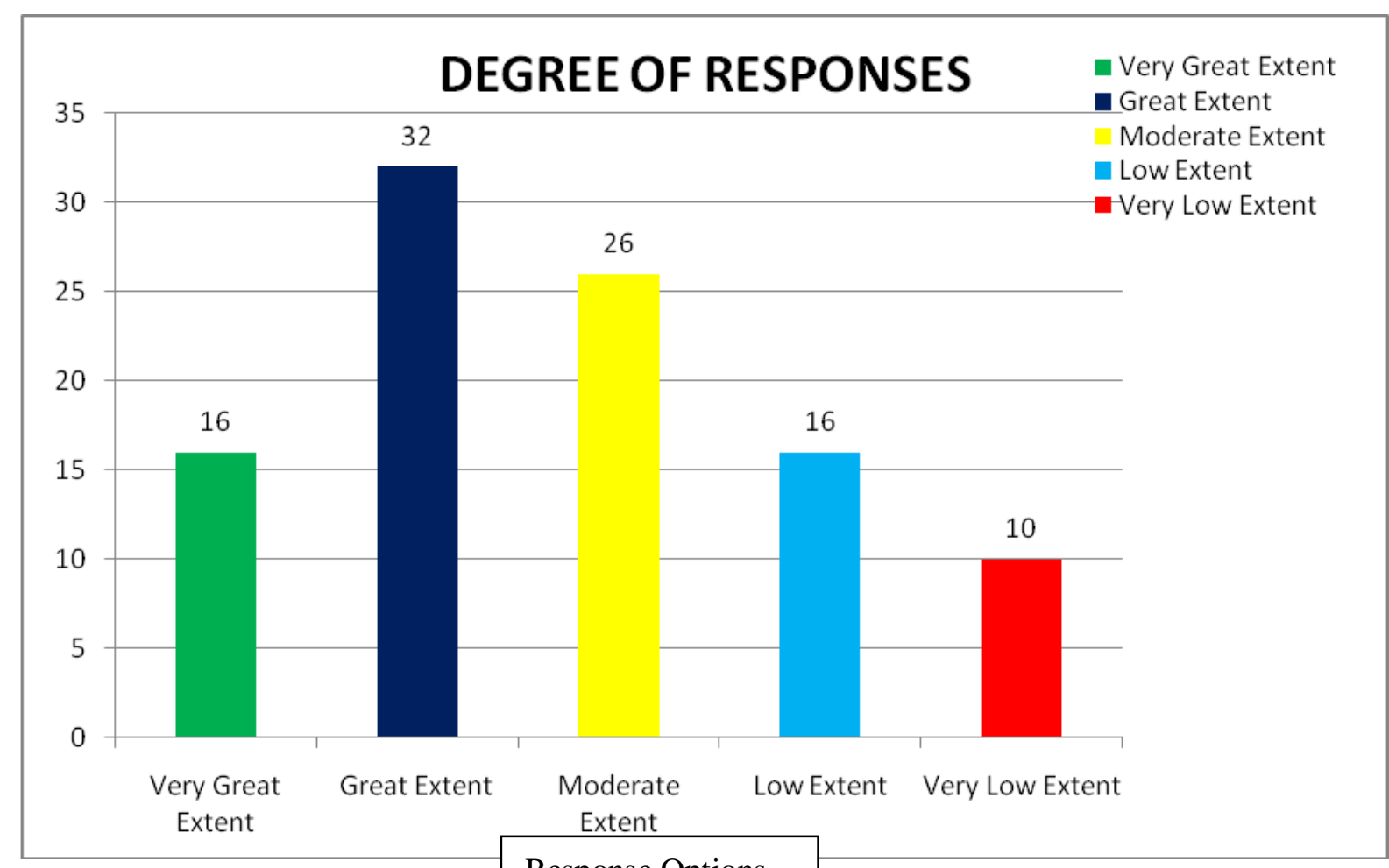

Figure 4.1 above shows that 16 Response Options dicated to a very great extent, $32 \%$ indicated to a great extent, $26 \%$ indicated moderate extent, while $16 \%$ of the responses indicated low extent and $10 \%$ indicated very low extent that brand sound influence repeat purchase of power generating plants in Rivers state.

It was concluded that to a great extent brand sound influences repeating purchase of power generating plants in Rivers state.

\section{Research Question 2}

To what extent does brand heat generation influence customer referral of power generating plant in Rivers State?

Figure 2: represent is a bar chart showing the responses of the respondents to research question two. 


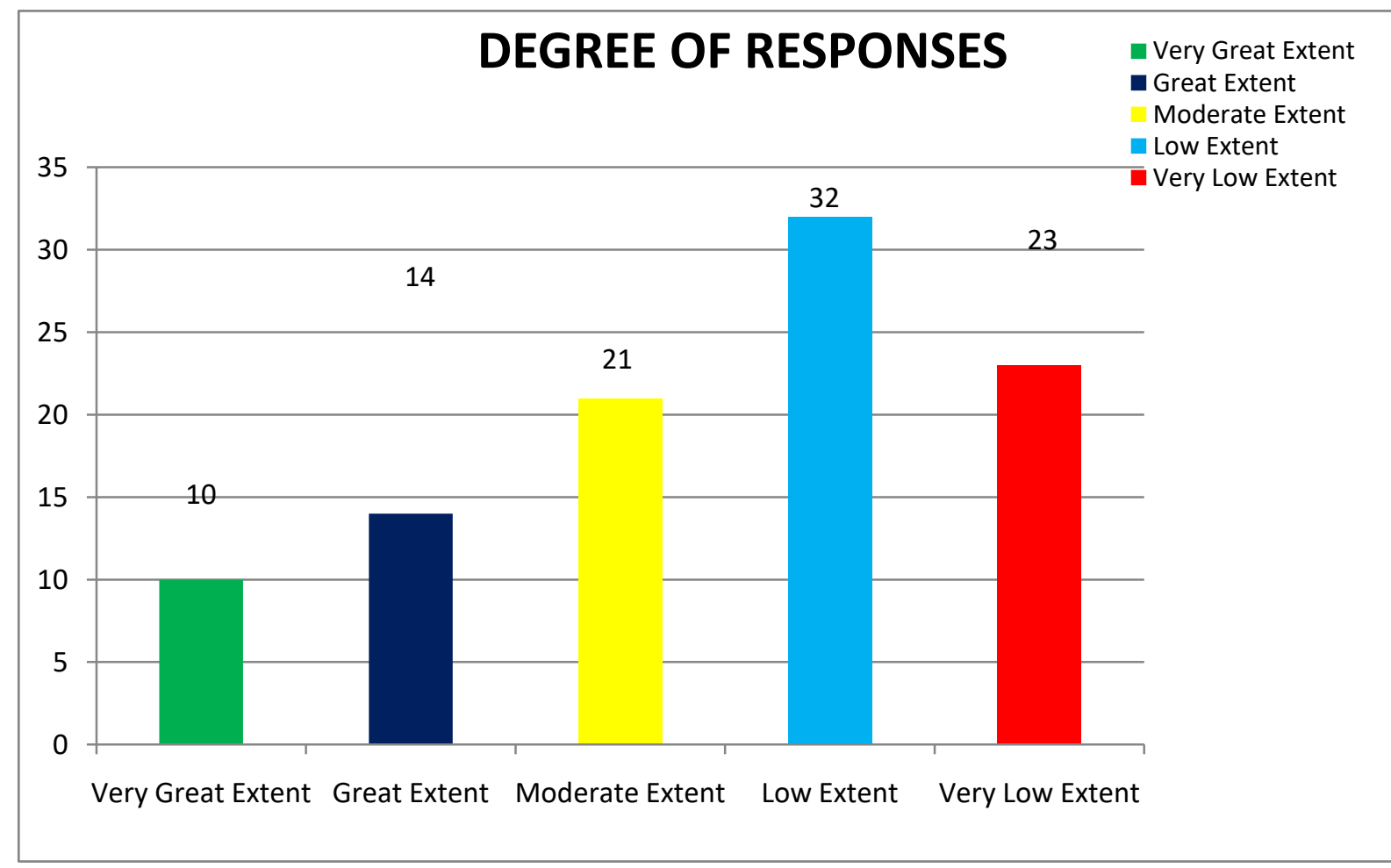

Figure 4.2 above shows that $10 \%$ of the responses indicated to a very great extent, $14 \%$ indicated to a great extent, $21 \%$ indicated moderate extent, while $32 \%$ of the responses indicated low extent and $23 \%$ indicated very low extent that brand heat generation influence customer referral of power generating plant in Rivers State?

It was concluded that brand heat generation lowly influence customer referral of power generating plants in Rivers state.

\section{Research Question 3}

To what extent does green protection determine customer loyalty of power generating plant in Rivers State?

Figure 3: represent is a bar chart showing the responses of the respondents to research question three.

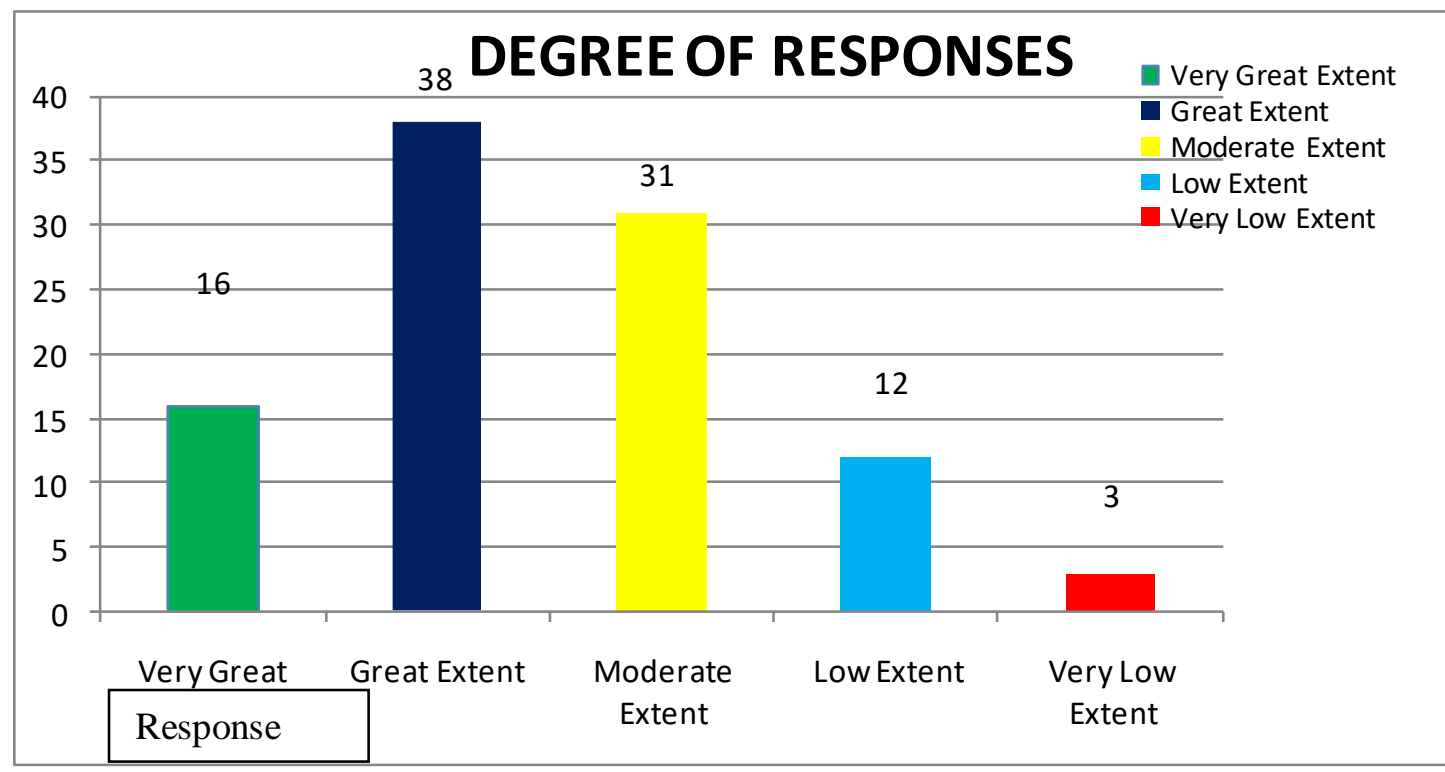

Figure 4.3 above shows that $16 \%$ of the responses indicated to a very great extent, $38 \%$ indicated to a 
great extent, $31 \%$ indicated moderate extent; while $12 \%$ of the responses indicated low extent and $3 \%$ indicated to a very low extent that green protection determine customer loyalty of power generating plant in Rivers State.

It was concluded that to a great extent green protection determine customer loyalty of power generating plant in Rivers State.

\section{Hypothesis 1:}

There is no significant relationship between brand sound and repeat purchase of power generating plant in Rivers State.

Table 5: Hypothesis One Computation of PPMC Coefficient (r) using The Deviation Method

\begin{tabular}{|c|c|c|c|c|c|c|c|}
\hline $\mathrm{N}$ & $\mathrm{X}$ & $\mathrm{Y}$ & $\mathrm{X}-\overline{\mathrm{X}}$ & $\mathrm{Y}-\overline{\mathrm{Y}}$ & $(\mathrm{X}-\overline{\mathrm{X}})^{2}$ & $(\mathrm{Y}-\overline{\mathrm{Y}})^{2}$ & $(\mathrm{X}-\overline{\mathrm{X}})(\mathrm{Y}-\overline{\mathrm{Y}})$ \\
\hline $\mathrm{A}$ & 30 & 45 & -0.6 & 14.2 & 0.36 & 201.64 & -8.52 \\
\hline $\mathrm{B}$ & 64 & 56 & 33.4 & 25.2 & 115.56 & 635.04 & 841.68 \\
\hline $\mathrm{C}$ & 39 & 33 & 8.4 & 2.2 & 70.56 & 4.84 & 18.48 \\
\hline $\mathrm{D}$ & 16 & 14 & -14.6 & -16.8 & 213.16 & 282.24 & 245.28 \\
\hline $\mathrm{E}$ & 4 & 6 & -26.6 & -24.8 & 707.56 & 615.04 & 659.68 \\
\hline 5 & $\Sigma X=153$ & $\Sigma \mathrm{Y}=154$ & & & $\Sigma(\mathrm{X}-\overline{\mathrm{X}})^{2}=2107.2$ & $\begin{array}{c}\Sigma(\mathrm{Y}-\overline{\mathrm{Y}})^{2} \\
=1738.8\end{array}$ & $\begin{array}{l}\Sigma(\mathrm{X}-\overline{\mathrm{X}})(\mathrm{Y}-\overline{\mathrm{Y}}) \\
=1756.6\end{array}$ \\
\hline
\end{tabular}

Decision rule: Since $r$ calculated is greater than $r$ critical, we therefore reject $\mathrm{Ho}_{1}$ and accept $\mathrm{Ha}_{1}$ which states that there is a relationship between brand sound and repeat purchase of power generating plants in Rivers state.

Conclusion: It was concluded that there is a great significant correlation between brand sound and repeat purchase of power generating plants in Rivers state. Hence customers consider sound in their purchase of power generating plants in Rivers State.

Hypothesis 2

There is no significant relationship between brand heat generation and customer referral of power generating plant in Rivers State.

Table 4.6: Hypothesis Two Computation of PPMC Coefficient (r) using The Deviation Method

\begin{tabular}{|c|c|c|c|c|c|c|c|}
\hline $\mathrm{N}$ & $\mathrm{X}$ & $\mathrm{Y}$ & $\mathrm{X}-\overline{\mathrm{X}}$ & $\mathrm{Y}-\overline{\mathrm{Y}}$ & $(\mathrm{X}-\overline{\mathrm{X}})^{2}$ & $(\mathrm{Y}-\overline{\mathrm{Y}})^{2}$ & $(\mathrm{X}-\overline{\mathrm{X}})(\mathrm{Y}-\overline{\mathrm{Y}})$ \\
\hline $\mathrm{A}$ & 20 & 25 & -3.8 & 1 & 14.44 & 1 & -3.8 \\
\hline $\mathrm{B}$ & 24 & 28 & 0.2 & 4 & 0.04 & 16 & 0.8 \\
\hline $\mathrm{C}$ & 33 & 27 & 9.2 & 3 & 84.64 & 9 & 27.6 \\
\hline $\mathrm{D}$ & 32 & 28 & 8.2 & 4 & 67.24 & 16 & 32.8 \\
\hline $\mathrm{E}$ & 10 & 12 & -13.8 & -12 & 190.44 & 144 & 165.6 \\
\hline 5 & $\Sigma X=119$ & $\Sigma \mathrm{Y}=120$ & & & $\Sigma(\mathrm{X}-\overline{\mathrm{X}})^{2}=356.8$ & $\begin{array}{l}\Sigma(\mathrm{Y}-\overline{\mathrm{Y}})^{2} \\
=186\end{array}$ & $\begin{array}{l}\Sigma(\mathrm{X}-\overline{\mathrm{X}})(\mathrm{Y}-\overline{\mathrm{Y}}) \\
=223\end{array}$ \\
\hline
\end{tabular}

Decision rule: Since $r$ calculated is less than $r$ critical, we therefore accept $\mathrm{Ho}_{2}$ which states that there is no significant relationship between brand heat generation and customer referral of power generating plant in Rivers State.

Conclusion: It was concluded that there is a low significant correlation between brand heat generation and customer referral of power generating plant in Rivers State. Hence customers do not refer power generating plants by recognizing heat generation in Rivers State. 


\section{Hypothesis 3}

There is no significant relationship between green protection and customer loyalty of power generating plant in Rivers State.

Table 6: Hypothesis Three Computation of PPMC Coefficient (r) using The Deviation Method

\begin{tabular}{|c|c|c|c|c|c|c|c|}
\hline $\mathrm{N}$ & $\mathrm{X}$ & $\mathrm{Y}$ & $\mathrm{X}-\overline{\mathrm{X}}$ & $\mathrm{Y}-\overline{\mathrm{Y}}$ & $(\mathrm{X}-\overline{\mathrm{X}})^{2}$ & $(\mathrm{Y}-\overline{\mathrm{Y}})^{2}$ & $(\mathrm{X}-\overline{\mathrm{X}})(\mathrm{Y}-\overline{\mathrm{Y}})$ \\
\hline $\mathrm{A}$ & 40 & 35 & 4.6 & 2.2 & 21.16 & 4.84 & 10.12 \\
\hline $\mathrm{B}$ & 76 & 68 & 40.6 & 35.2 & 1648.36 & 1239.04 & 1429.12 \\
\hline C & 39 & 48 & 3.6 & 15.2 & 12.96 & 231.04 & 54.72 \\
\hline D & 20 & 12 & -15.4 & -20.8 & 237.16 & 432.64 & 320.32 \\
\hline E & 2 & 1 & -33.4 & -31.8 & 1115.56 & 1011.24 & 1062.12 \\
\hline 5 & $\Sigma \mathrm{EX}=177$ & $\Sigma \mathrm{Y}=164$ & & & $\Sigma(\mathrm{X}-\overline{\mathrm{X}})^{2}=3025.2 .20$ & $\begin{array}{l}\Sigma(\mathrm{Y}-\overline{\mathrm{Y}})^{2} \\
=2708.8\end{array}$ & $\begin{array}{l}\Sigma(\mathrm{X}-\overline{\mathrm{X}})(\mathrm{Y}-\overline{\mathrm{Y}}) \\
=2876.4\end{array}$ \\
\hline
\end{tabular}

Decision rule: Since $\mathrm{r}$ calculated is greater than $\mathrm{r}$ critical, we therefore reject $\mathrm{Ho}_{3}$ and accept $\mathrm{Ha}_{3}$ which states that there is a significant relationship between green protection and customer loyalty of power generating plant in Rivers State.

Conclusion: It was concluded that there is a great significant correlation between green protection and customer loyalty of power generating plant in Rivers State. Hence customers take into consideration emission effects of power generating plants on the bio environment when making product loyalty decision in Rivers State.

\section{CONCLUSION}

Based on the analysis of data, the study concluded that there is significant influence of consumer environmental consciousness on brand preference in Rivers State. It is therefore worthy of note that there is a great correlation between brand sound and repeat purchase of power generating plants in Rivers state, there is a low correlation between brand heat generation and customer referral of power generating plant in Rivers State and that there is a great correlation between green protection and customer loyalty of power generating plant in Rivers State.

\section{RECOMMENDATIONS}

The study offers the following recommendations in line with the objectives of this research to the consumers of power generating plants in Rivers State.

1. Consumers should maintain purchase of noiseless power generating plants in Rivers State for environmental protection and comfort for its users.

2. Consumers should be educated on the effect of power plant heat generation on the environment in Rivers State to effect brand referral.

3. Consumers in Rivers State should be loyal to power generating plants that emit less carbon monoxide for green house protection.

\section{REFERENCES}

Aditi, M., Rameshwar, D., Omprakash, K. G.\& Zongwei, L. (2017). Dynamics of environmental consciousness and green purchase behaviour: an empirical study. International Journal of Climate Change Strategies and Management. 1756-8692

Alamro, A. and Rowley, J. (2011). Antecedents of brand preference of mobile telecommunications administrations.Journal of Product \& Brand Management, 20(6).

Bergman, P., Sköld, A., Västfjäll, D., \& Fransson, N. (2009). Perceptual and emotional categorization of sound. Journal of the Acoustical Society of America, 126(6).

Carpenter, G.S. and Nakamoto, K. (1994). Reflections on consumer preference formation and 
pioneering advantage. Journal of Marketing Research, 31(4).

Chernev, A., Hamilton, R. and Gal, D. (2011). Competing for consumer identity: limits to selfexpression and the perils of lifestyle branding. Journal of Marketing, 75(3).

Elijah, A. A. (2017). Theories and concepts for human behavior in environmental preservation. Journal of Environmental Science and Public Health. (1)2.

Huang, C. and Kung, F. (2011).Environmental consciousness and intellectual capital management: evidence from Taiwan's manufacturing industry. Management Decision, (49)9

Ibimilua, F. O. \& Adewale, F. I. (2014). Environmental challenges in Nigeria: Typology, Spatial Distribution, Repercussions and Way Forward. American International Journal of Social Science.3(2).

Iftekhar, Z., Arnab, T., Ali, M., Shidujaman, M. d. \& Mayen, H. (2013).Consideration of Environmental Effect of Power Generation: Bangladesh Perspective Energy and Power Engineering, 1521-1525.

John, S. (2019). The rise of eco-friendly products. Retrieved from https://www.thomasnet.com/insights/the-rise-of-eco-friendly-products/. accessed on 6/8/2019.

Matthew, W. (2013). Does green management matter for donation intentions? the influence of environmental consciousness and environmental importance. Management Decision, 51(8).

Muhammad, A. H., Muhammad, F. K. \& Ali, A. (2014). Green awareness effects on consumers' purchasing decision: A Case of Pakistan. Global Journal of Management and Business Research: EMarketing. (14)6.

Norazah, M. S. (2013). Green awareness effects on consumers' purchasing decision: Some Insights from Malaysia. Green Awareness Effects, IJAPS,(9)2.

Najam, Z. \&Maryam, S. (2016) Factors effecting consumer brand preferences in automobile industry . Singaporean Journal of business economics, and management studies (SJBem).(5)3.

Revill, K. P., Namy, L. L., DeFife, L. C.\& Nygaard, L. C. (2014). Cross-linguistic sound symbolism and cross modal correspondence: evidence from fMRI and DTI. Brain \& Language, 128(1).

Rinkesh, O. (2019). What is the greenhouse effect? Retrieved from https://www.conserve-energyfuture.com/greenhouseeffectcauses.php. accessed on 8/8/2019.

Reham, E., Ahmad, G., Zahir, I. \& Ying F. (2016). Brand preference and repurchase intention model: the role of consumer experience. Journal of Marketing Management (32)13-14

Wilms, J.\& Görmann, M. (2010). Sound engineering für elektroautos: Der Ton macht die Musik. Süddeutsche Zeitung, p. 31.

Zelezny, L.C. and Schultz, P. (2000). "Psychology of promoting environmentalism: promoting environmentalism”, Journal of Social Issues. 56(3).

APPENDIX

QUESTIONNAIRE

Your name:

Name of brand to assess

How long have you been using the brand: 1-5 years

Gender: Male

Female

$6-10$ years

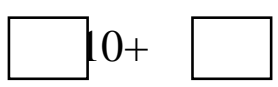

\section{SECTION B}

Please tick $(\sqrt{ })$ which describes your responses, noting the codes below

$\mathrm{VHE}=$ High Extent

$\mathrm{HE}=$ Moderate Extent

$\mathrm{LE} \quad=\quad$ Low Extent

VLE $=$ Very Low Extent 
Independent Variable; Dimensions Products

INSTRUCTION: Please tick only one option.

\begin{tabular}{|c|c|c|c|c|c|c|}
\hline $\mathbf{S} / \mathbf{N}$ & BRAND SOUND & VGE & GE & ME & LE & VLE \\
\hline 1 & $\begin{array}{l}\text { The brand of power generating plant I own produce } \\
\text { less noise. }\end{array}$ & & & & & \\
\hline 2 & $\begin{array}{l}\text { I am aware of the negative effect of noise caused by } \\
\text { power plants on the environment. }\end{array}$ & & & & & \\
\hline 3 & $\begin{array}{l}\text { I prefer power plant with low sound to the one with } \\
\text { higher sound. }\end{array}$ & & & & & \\
\hline \multirow[t]{2}{*}{4} & $\begin{array}{l}\text { Power generating plant's sound dictate its viability } \\
\text { and should be considered above other factors. }\end{array}$ & & & & & \\
\hline & BRAND HEAT GENERATION & & & & & \\
\hline 5 & $\begin{array}{l}\text { I am aware that power generating plant contributes to } \\
\text { global warming. }\end{array}$ & & & & & \\
\hline 6 & $\begin{array}{l}\text { My brand of power plant generates minimum heat and } \\
\text { is eco friendly. }\end{array}$ & & & & & \\
\hline 7 & $\begin{array}{l}\text { Power plant productivity is not determined by heat } \\
\text { generation as assumed. }\end{array}$ & & & & & \\
\hline \multirow[t]{2}{*}{8} & $\begin{array}{l}\text { Heat generated by power plants creates discomfort in } \\
\text { the neighborhood. }\end{array}$ & & & & & \\
\hline & GREEN PROTECTION & & & & & \\
\hline 9 & $\begin{array}{l}\text { My power plant did not emit smoke into the } \\
\text { environment. }\end{array}$ & & & & & \\
\hline 10 & $\begin{array}{l}\text { Climatic change is mostly caused by emission from } \\
\text { power generating plants }\end{array}$ & & & & & \\
\hline 11 & $\begin{array}{l}\text { The green house effect is caused by unnecessary heat } \\
\text { emission from human activities which is preventable. }\end{array}$ & & & & & \\
\hline 12 & $\begin{array}{l}\text { Human lives and other living organisms feed on the } \\
\text { environment and should be protected. }\end{array}$ & & & & & \\
\hline$\overline{\mathbf{S} / \mathbf{N}}$ & REPEAT PURCHASE & VGE & $\overline{\text { GE }}$ & 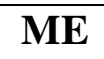 & $\overline{\mathbf{L E}}$ & VLE \\
\hline 1 & $\begin{array}{l}\text { Sound is a major factor in power plant purchase } \\
\text { decision. }\end{array}$ & & & & & \\
\hline 2 & $\begin{array}{l}\text { Purchasing power plant over and over is an indication } \\
\text { that the brand sound is friendly to the environment. }\end{array}$ & & & & & \\
\hline 3 & $\begin{array}{l}\text { I have bought more than one of same brand of power } \\
\text { plant in recent time. }\end{array}$ & & & & & \\
\hline \multirow[t]{2}{*}{4} & $\begin{array}{l}\text { Customer buys products regularly when they are } \\
\text { satisfied with the product. }\end{array}$ & & & & & \\
\hline & CUSTOMER REFERRAL & & & & & \\
\hline 5 & $\begin{array}{l}\text { I received referral of my brand of power generator } \\
\text { from a loyal customer. }\end{array}$ & & & & & \\
\hline 6 & $\begin{array}{l}\text { Power generator with less heat generator received } \\
\text { high referral in the market. }\end{array}$ & & & & & \\
\hline 7 & I have referral my brand of power generator because & & & & & \\
\hline
\end{tabular}




\begin{tabular}{|l|l|l|l|l|l|}
\hline & $\begin{array}{l}\text { of its environmental friendly nature in heat } \\
\text { generation. }\end{array}$ & & & \\
\hline 8 & $\begin{array}{l}\text { Products that perform satisfactorily are rewarded with } \\
\text { high referral. }\end{array}$ & & & \\
\hline 9 & \multicolumn{1}{|c|}{ CUSTOMER LOYALTY } & & \\
\hline 10 & $\begin{array}{l}\text { I have maintained my brand of power generator for } \\
\text { many years. }\end{array}$ & $\begin{array}{l}\text { I consistently used a particular brand of power plant } \\
\text { because it produces less carbon 4 oxide. }\end{array}$ & & & \\
\hline 11 & $\begin{array}{l}\text { Customer loyalty of power generating plants is an } \\
\text { indication that the brand support environment } \\
\text { protection. }\end{array}$ & & & \\
\hline 12 & $\begin{array}{l}\text { I will still make purchase of my power plant brand } \\
\text { despite price increment. }\end{array}$ & & & & \\
\hline
\end{tabular}

